W wielu pracach przyrodnicy podaja pomiary tych ezy innych wielkości; pomiary te zwykle służą do dalszych opracowań i wniosków. Zrozumiała jest więc tendencja badaczy do jak najdokładniejszego mierzenia. Często jednak materiały eksperymentalne podaje się z fikcyjną dokładnością. Można to zanważyé obserwując częstość występowania cyfr 0,1 , $2,3,4,5,6,7,8,9$ na ostatnim miejscu znaczącym pomiarów. Jeśli przedział mierzonej wielkości jest duży w porównaniu z przedziałem wynikającym ze zmiany o jednostke ostatniej cyfry znaczącej, to częstosici te powinny być w przybliżeniu równe. Np. cyfra 0 powinna występować równie często, jak cyfra 9. A oto kilka przykładów opracowanych ostatnio przez Grupe Zastosowań Przyrodniczych i Gospodarczych Instytutu Matematycznego PAN, a wziętych z innych pracowni naukowych.

A. Zoologowie zmierzyli 187 ezaszek szczurz̧ych z rzekomą dokładnością do $0,1 \mathrm{~mm}$. Zmierzono:

TABLICA 1

Czaszki szozurze

\begin{tabular}{c|c|c|c}
\hline $\begin{array}{c}\text { Ostatnia } \\
\text { cyfra }\end{array}$ & $\begin{array}{c}\text { Dlugość } \\
\text { podsta- } \\
\text { wy } \\
\text { czaszzi }\end{array}$ & $\begin{array}{c}\text { Szero- } \\
\text { kość } \\
\text { czaszki }\end{array}$ & $\begin{array}{c}\text { Wyso- } \\
\text { kość } \\
\text { potylioy }\end{array}$ \\
\hline 0 & 78 & 76 & 67 \\
1 & 5 & 0 & 4 \\
2 & 6 & 9 & 7 \\
3 & 12 & 12 & 16 \\
4 & 10 & 17 & 16 \\
5 & 35 & 28 & 39 \\
6 & 7 & 20 & 12 \\
7 & 11 & 5 & 12 \\
8 & 17 & 13 & 7 \\
9 & 6 & 7 & 7 \\
\hline$\chi_{0}^{2}$ & 246,6 & 225,7 & 185,9 \\
\hline
\end{tabular}

1) dhugość podstawy czaszki (od $23,0 \mathrm{~mm}$ do $48,0 \mathrm{~mm}$ ),

2) szerokość czaszki na grzebieniach skroniowych (od $9,6 \mathrm{~mm}$ do $16,0 \mathrm{~mm}$ ),

3) wysokość potylicy (od $5,9 \mathrm{~mm}$ do $12,5 \mathrm{~mm}$ ).

Spośród wyników każdego z pomiarów około 19 powinno kończyć się na 0, tyleź na 1, na 2 itd. Okazuje się, że jest zupelnie inaczej. Tablica 1 zawiera ilości cyfr $0,1,2,3,4,5,6,7,8,9$ na ostatnim miejscu tych wyników. Na przykład przy pomiarze długości czaszki 78 wyników pomiaru podano w całkowitych milimetrach (ostatnia cyfra znacząca, tj. pierwsza 
cyfra po przecinku była zerem); 5 wyników miało po przecinku cyfrę 1; 6 pomiarów cyfre 2 itd.

B. Antropologowie zmierzyli stopy poborowych $\mathrm{z}$ powiatu lubelskiego z rzekomq dokładnością do $1 \mathrm{~mm}$. Zmierzono:

1) długość stopy (od $218 \mathrm{~mm}$ do $350 \mathrm{~mm}$ ),

2) wysokość kostki (od $50 \mathrm{~mm}$ do $90 \mathrm{~mm}$ ),

3) obwód przez palce (od $200 \mathrm{~mm}$ do $310 \mathrm{~mm}$ ),

4) obwód przez podbicie (od $200 \mathrm{~mm}$ do $300 \mathrm{~mm}$ ),

5) obwód przez piętę i podbicie (od $245 \mathrm{~mm}$ do $396 \mathrm{~mm}$ ). u 357.

Zmierzono 361 poborowych, przy tym długośc stopy zmierzono tylko

Tablica 2 zawiera ilosci eyfr $0,1,2,3,4,5,6,7,8,9$ na ostatnim miejscu.

TABLICA 2

Stopy poborowych

\begin{tabular}{c|c|c|c|c|c}
\hline $\begin{array}{c}\text { Ostatnia } \\
\text { eyfra }\end{array}$ & $\begin{array}{c}\text { Długośc } \\
\text { stopy }\end{array}$ & $\begin{array}{c}\text { Wysokość } \\
\text { kostki }\end{array}$ & $\begin{array}{c}\text { Obwód przez } \\
\text { palce }\end{array}$ & $\begin{array}{c}\text { Obwód przez } \\
\text { podbicie }\end{array}$ & $\begin{array}{c}\text { Obwód przez } \\
\text { piete } \\
\text { i podbicie }\end{array}$ \\
\hline 0 & 87 & 51 & 229 & 273 & 277 \\
1 & 26 & 35 & 5 & 0 & 2 \\
2 & 31 & 35 & 20 & 11 & 16 \\
3 & 20 & 44 & 19 & 8 & 10 \\
4 & 21 & 42 & 10 & 9 & 4 \\
5 & 63 & 30 & 37 & 36 & 25 \\
6 & 24 & 39 & 7 & 2 & 12 \\
7 & 29 & 32 & 13 & 13 & 7 \\
8 & 28 & 30 & 18 & 9 & 7 \\
9 & 28 & 23 & 3 & 0 & 1 \\
\hline$x_{0}^{2}$ & 119,2 & 16,4 & 1169,4 & 1763,8 & 1798,9 \\
\hline
\end{tabular}

W obu podanych tablicach - z wyjątkiem kolumny „wysokość kostki" - widzimy rażącą niejednostajność występowania poszczególnych cyfr na ostatnim miejscu znaczącym. Cyfra 0 we wszystkich kolumnach występuje znacznie częściej niż pozostałe. W niektórych kolumnach dostrzegamy także nadmierną częstośc występowania cyfry 5.

O czym to swiadczy?

Gdyby pomiary były robione rzeczywiście z taką dokładnością, na jaką wskazuje ilosć zapisywanych cyfr, wówczas końcowe cytry występowałyby z jednakową mniej więcej częstością. To znaczy, tyle samo w przybliżeniu byłoby czaszek o długości zakończonej na 0, co na 1, 2, itd.

Zaobserwowanej niejednorodności nie można w żaden sposób wytłumaczyé wahaniem przypadkowym. Prawdopodobieństwo tego,- że przy- 
padkiem otrzyma się taką wielką niejednorodność, oblicza się za pomocą kryterinm $\chi^{2}$. W ostatnim wierszu każdej tablicy podano wielkości $\chi_{0}^{2}$ obliczone przy porównaniu każdej kolumny tablicy z kolumną teoretyezną, w której w każdym wierszu jest ta sama liezba; dla tablicy 1 jest to liczba 18,7 , dla tablicy 2 zaś 36,1 . Wartość $\chi_{0}^{2}$ obliczona dla ilości różnych eyfr na ostatnim miejseu wyników pomiaru długości podstawy czaszki szczura wynosi 246,6, co jest wartością bardzo dużą. Prawdopodobieństwo przypadkowego zajścia takiego zdarzenia jest więc znikomo małe, praktycznie równe zeru, gdyż według tablicy rozkładu $\chi^{2}$ dla 9 stopni swobody $P\left(\chi^{2}>27,9\right)=0,001$. W pozostałych kolumnach tablic 1 i 2 (oprócz kolumny drugiej w tablicy 2, tj. wysokości kostki) otrzymujemy wielkości $\chi_{0}^{2}$ mniejsze lub większe niż $w$ omawianym przykładzie, zawsze jednak prawdopodobieństwo przypadkowego uzyskania takich wartości jest znikomo małe. Takich wielkich różnic nie można kłaśé na karb przypadku. Dowodzą one, że we wszystkich pomiarach $\mathrm{w}$ tablicach 1 i 2 (oprócz wysokości kostki w stopach poborowych) ostatniz̨ cyfrę zapisywano błędnie. Nadmiar eyfr 0 i 5 i niedobór eyfr sąsiednich świadczy. o tendencji (byé może podświadomej) do zaokrąglania wyników. Nie możemy nawet

\begin{tabular}{c|c|c}
\multicolumn{3}{c|}{ TABLICA 3 } \\
\multicolumn{3}{|c}{ Czaszki ludzkie } \\
\hline $\begin{array}{c}\text { Ostatnia } \\
\text { cyfra }\end{array}$ & $\begin{array}{c}\text { Wysokość } \\
\text { czaszki } \\
(b-a b)\end{array}$ & $\begin{array}{c}\text { Długość } \\
\text { czaszki } \\
(g-o p)\end{array}$ \\
\hline 0 & 72 & 82 \\
1 & 50 & 66 \\
2 & 77 & 71 \\
3 & 56 & 59 \\
4 & 62 & 49 \\
5 & 63 & 86 \\
6 & 53 & 69 \\
7 & 63 & 67 \\
8 & 47 & 79 \\
9 & 56 & 30 \\
\hline razem pomiarów: 599 & 658 \\
$\chi_{0}^{2}$ & 13,4 & 37,9
\end{tabular}

z pomiarów czaszek szczurzych, zanotowanych z rzekomą dokładnością do $0,1 \mathrm{~mm}$, uzyskać dokładności $0,2 \mathrm{~mm}$, gdyż zaokrąglanie ostatniej cyfry (na przykład do parzystej) nie wiele poprawi. Nawet zaokrąglenie do $0,5 \mathrm{~mm}$ da zbyt dużo pomiarów zakończonych na $0 \mathrm{w}$ porównaniu z pomiarami zakończonymi-na 5 . W tym więc przypadku ostatnia cyfra jest zupełnie bezwartościowa i wykorzystując materiał musimy ją odrzucić.

C. Nieco lepiej przedstawia się sprawa w dużym materiale (ponad 600) czaszek ludzkich, wziętym z pracy F. Wokroja [2]. Można się było spodziewać, że dla tego materiału rozkład ostatnich cyfr będzie $w$ przybliżeniu jednostajny, gdyż czaszka ludzka jest przedmiotem dużym, sztywnym, a przyrzq̨dy pomiarowe używane przez antropologów pozwalają mierzyć z dokładnością do $1 \mathrm{~mm}$.

Tablica 3 zawiera wyniki pomiaru dla wybranych cech:

1) wysokość czaszki $b-a b$ (od $117 \mathrm{~mm}$ do $151 \mathrm{~mm}$ ),

2) długość czaszki $g-o p$ (od $246 \mathrm{~mm}$ do $313 \mathrm{~mm}$ ). 
Rozpatrzymy pierwszą kolumnę tablicy 3.

Częstości ostatnich cyfr nie są tu idealnie zgodne, jednak ich odstępstwa od jednostajności można wytłumaczyé wahaniem przypadkowym. Wartość $\chi_{0}^{2}$ obliczona dla pierwszej kolumny równa się 13,4, a prawdopodobieństwo dla 9 stopni swobody przypadkowego przekroczenia tej wielkości jest 0,10 .

$\mathrm{Z}$ tego wynika, że pomiary $w$ kolumnie pierwszej tablicy 3 nie są obarczone takim dụżym błędem, jak pomiary w tablicach 1 i 2 . Jednak już druga kolumna tablicy 3 wykazuje większe i statystycznie istotne różnice. Mimo pozornie jednakowych warunków pomiaru obu cech antropologicznych, njętych $w$ tablicy 3 , pomiary drugiej $z$ nich wykazują podobne tendencje, jak poprzednio dyskutowane pomiary $z$ tablic 1 i 2 . Nawet więc przy dobrych warunkach pomiarów trudno się ustrzec od pewnych tendencji zniekształeających materiały pomiarowe. Można stąd wyciągnąé następujące wnioski:

1. Głównym źródłem omawianych tu błędów jest, jak się wydaje, zaokrąglanie wyników pomiarów „na oko" wtedy, gdy wielkosé mierzona pada między dwie sąsiednie kreski podziałki i musimy cechę którejś z nich przyjąć za wynik pomiaru. Decyzję tę ułatwia proponowana przez H. Steinhausa [1] specjalna podziałka, w której cechuje się nie kreski, ale przedziały między kreskami:

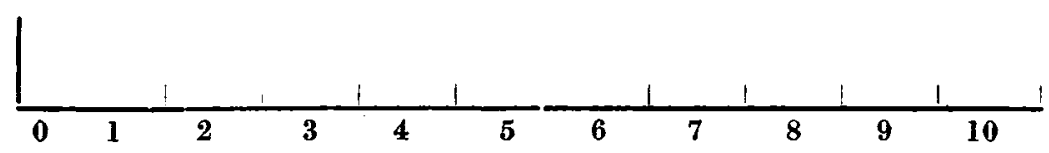

Przy takiej podziałce unikamy zastanawiania się w przypadku, gdy mierzony przedmiot ma na przykład okolo $3,5 \mathrm{~mm}$, czy to już jest $4 \mathrm{~mm}$, czy jeszeze $3 \mathrm{~mm}$, gdyż widzimy wyraźnie, czy koniec przedmiotu pada przed kreską odgraniczającą przedział 3 od 4, czy za nią.

2. Przed rozpoczęciem pomiarów należy ustalié, jaką dokładność pomiaru pozwalają osiągnąé warunki techniczne.

Np. przy pomiarach stóp poborowych tylko wysokość kostki mierzona byla precyzyjnym przyrządem pomiarowym, pozwalającym dokładnie ustawić noge i odczytać wynik z dokładnością $1 \mathrm{~mm}$. Natomiast inne pomiary wykonane taśmą nie mogły mieć dokładności $1 \mathrm{~mm}$, tym bardziej, że stopa jest przecież odksztalcalna.

3. Można również przed rozpoezęciem dużej ilości pomiarów (np. wielu setek) zrobić serię kontrolną dla kilkudziesięciu pomiarów i sprawdzić jednostajność występowania eyfr na ostatnim miejseu. 


\title{
Prace eytowane
}

[1] J. Eukaszewicz i H. Steinhaus, $O$ mierzeniu przez kalibrowanie, Zastosowania Matematyki 2 (1955), str. 225 -231.

[2] F. Wokroj, Wczesnośredniowieczne czaszki polskie z Ostrowa Lednickiego, Materialy i Prace Antropologiczne 1 (1953), str. 60-134.

INSTYTUT MATEMATYCZNY POLSKIEJ AKADEMII NAUK

Praca wplynęla dinia 19. 4. $1955 \mathrm{r}$.

\author{
A. ХУ СКО В С КАЯ (Вроцлая) \\ О ТОЧНОСТИ НЕКОТОРЫХ ЕСТЕСТВОИСПЫТАТЕЛЬСКИХ ИЗМЕРЕНИИ
}

\section{PES 5 M E}

Опытный материал естествоиспытательских ивмерений часто подается с фиктивной точностью. Источником погрешностег является обьчно пренебрежение технического анализа достигнутой точноети и онругливание на-глаз результа. тов ивмерений.

В некоторых случаях такие погрешности можно обнаружить, аналивирує фреквенцию последней вначуцей цифры. В статье проанализировано таким об. разом несколько подлинных серии ивмерении д докавапо, что их төчность фиктивна.

A. H USKOWSKA (Wroclaw)

ON THE AOCURAOY OF SOME NATURAL SOIENOE MEASUREMENTS

SU M M A R Y

The experimental results of certain natural science measurements are often given with fictitious accuracy. The source of error lies in the neglect of technical analysis of the attainable accuracy and in rounding off the results of measurements at sight.

In a large number of cases it is possible to detect such errors by analysing the frequency of appearance of the last significant digit. The author analyses several authentic measurement series and proves that their accuracy is fictitious. 